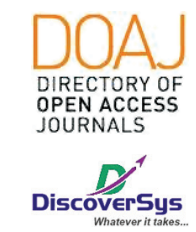

Published by DiscoverSys

\section{Gambaran fraktur elbow pada anak-anak di RSUP Sanglah tahun 2012-2013}

\author{
Ketut Arya Surya Pranata, ${ }^{1 *}$ IGST Nyoman Wien Arnaya ${ }^{2}$
}

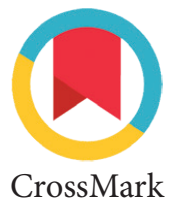

CrossMark

\title{
ABSTRACT
}

Introduction: Fracture is a loss of bone continuity, either total or partial, usually caused by trauma. Fractures in children are more common due to the immature musculoskeletal system, this is because the child is more susceptible to tears on joint surfaces, epiphyseal plates, aphophyseal insertion of large tendon muscle units. This study aims to determine the prevalence of elbow fracture in children at Sanglah Hospital Denpasar in 2012 until 2013.

Method: Study design using cross-sectional method, evaluating the characteristics of elbow fracture in children at Sanglah General Hospital in the period 2012 to 2013.
Results: Males tend to have more elbow fractures compared with females with a $73 \%$ proportion, based on the cause of overall fracture of the sample due to falling during activity, based on the fracture type more subjects experiencing fractures of the supracondylar humerus fracture compared with olecranon fractures as much as $93 \%$.

Conclusion: The prevalence of elbow fracture in children in Sanglah General Hospital in 2012-2013 is 15 cases, all caused by falling during the activity. The type of elbow fracture found in most children is a supracondylar humerus fracture.

Keywords: fracture, elbow, children.

Cite This Article: Pranata, K.A.S., Arnaya, I.G.S.T.N.W. 2019. Gambaran fraktur elbow pada anak-anak di RSUP Sanglah tahun 2012-2013. Intisari Sains Medis 10(2): 306-308. D0I: 10.15562/ism.v10i2.299

\section{ABSTRAK}

Latar Belakang: Fraktur merupakan hilangnya kontinuitas tulang, baik yang bersifat total maupun sebagian, biasanya disebabkan oleh trauma. Fraktur pada anak lebih sering terjadi dikarenakan sistem muskuloskeletal yang belum matang, hal ini disebabkan pada anak lebih rentan terhadap robekan pada permukaan sendi, lempeng epifiseal, insersi apofiseal dari satuan otot tendon yang besar.

Metode: Penelitian ini bertujuan untuk mengetahui gambaran dari fraktur elbow pada anak-anak di RSUP Sanglah Denpasar pada tahun 2012 hingga 2013. Rancangan penelitian ini menggunakan rancangan potong-lintang, melakukan evaluasi terhadap karakteristik dari fraktur elbow pada anak-anak di RSUP Sanglah pada periode 2012 hingga 2013.
Hasil: Laki-laki cenderung lebih banyak untuk mengalami fraktur elbow dibandingkan dengan perempuan yaitu dengan proporsi $73 \%$, berdasarkan penyebab fraktur keseluruhan sampel disebabkan oleh jatuh saat beraktifitas, berdasarkan jenis fraktur lebih banyak subjek yang mengalami fraktur suprakondiler humerus dibandingkan dengan fraktur olecranon yaitu dengan proporsi $93 \%$.

Simpulan: Prevalensi fraktur elbow pada anak-anak di RSUP Sanglah Denpasar pada tahun 2012-2013 sebanyak 15 kasus, seluruhnya disebabkan karena terjatuh saat beraktifitas. Jenis fraktur elbow yang ditemukan pada anak-anak terbanyak adalah fraktur suprakondiler humerus.
'Program Studi Pendidikan Dokter, Fakultas Kedokteran Universitas Udayana

${ }^{2}$ Bagian/SMF Orthopedi dan Traumatologi, Fakultas Kedokteran, Universitas UdayanaRSUP Sanglah Denpasar

${ }^{*}$ Correspondence to: Ketut Arya Surya Pranata, Program Studi Pendidikan Dokter, Fakultas Kedokteran Universitas Udayana aryapranata1995@gmail.com

Diterima: 04-07-2018

Disetujui: 16-04-2019

Diterbitkan: 01-08-2019

Kata kunci: fraktur, elbow, anak-anak.

Cite Pasal Ini: Pranata, K.A.S., Arnaya, I.G.S.T.N.W. 2019. Gambaran fraktur elbow pada anak-anak di RSUP Sanglah tahun 2012-2013. Intisari Sains Medis 10(2): 306-308. D0I: 10.15562/ism.v10i2.299

\section{PENDAHULUAN}

Fraktur merupakan hilangnya kontinuitas tulang, baik yang bersifat total maupun sebagian, biasanya disebabkan oleh trauma. Insiden fraktur secara keseluruhan adalah 11,3 dalam 1000 per tahun, pada laki-laki adalah 11,67 dalam 1000 penduduk per tahun, sedangkan pada perempuan 10,65 dalam 1000 penduduk per tahun. Gejala klasik fraktur adalah adanya riwayat trauma, rasa nyeri dan bengkak di bagian tulang yang patah, deformitas, gangguan fungsi muskuloskeletal, putusnya kontinuitas tulang, dan gangguan neurovaskular. ${ }^{1,5}$

Fraktur pada anak lebih sering terjadi dikarenakan sistem muskuloskeletal yang belum matang, hal ini disebabkan pada anak lebih rentan terhadap robekan pada permukaan sendi, lempeng epifiseal, insersi apofiseal dari satuan otot tendon yang besar. Hampir dari kebanyakan kasus fraktur pada 
anak-anak terjadi pada elbow dikarenakan pada usia 5-10 tahun anak-anak tersebut sedang dalam proses pematangan tulang. Dan pada usia tersebut anak-anak rentan sekali terkena fraktur akibat dari aktifitas fisik yang dilakukan oleh anak-anak seperti bermain dengan teman sebayanya atau sedang berolahraga. Fraktur elbow memiliki risiko yang tinggi setelah dilakukan penanganan. Karena fraktur elbow pada anak memiliki vaskularisasi yang baik sehingga proses penyembuhan fraktur berlangsung cepat. Oleh karena itu, operasi pembedahan harus segera dilakukan sebelum terjadinya komplikasi. Fraktur elbow merupakan kasus trauma paling umum yang terjadi pada anak-anak sekitar $15 \%$ fraktur yang terjadi pada anak-anak adalah fraktur elbow, dan $85 \%$ penyebab operasi orthopaedi terjadi karena fraktur elbow. Fraktur elbow terdiri dari supracondylar, lateral condyle, neck of radius, medial epicondyle, olecranon, head of radius, intercondylar fracture. ${ }^{1,2}$

Penelitian ini bertujuan untuk mengetahui gambaran dari fraktur elbow pada anak-anak di RSUP Sanglah Denpasar pada tahun 2012 hingga 2013.

\section{METODE}

Penelitian ini merupakan penelitian deskriptif yang menggunakan rancangan potong lintang terhadap pasien fraktur elbow pada anak-anak di Rumah Sakit Umum Pusat Sanglah Denpasar tahun 2012-2013.Penelitian ini bertujuan untuk mengetahui prevalensi fraktur elbow pada anakanak. Penelitian dilakukan di bagian Ortopedi dan Traumatologi Rumah Sakit Umum Pusat Sanglah, Denpasar. Penelitian dilakukan pada bulan januari sampai dengan Desember 2013. Kriteria inklusi pada penelitian ini adalah semua pasien fraktur elbow pada anak-anak di Rumah Sakit Umum Pusat Sanglah, Denpasar tahun 2012-2013. Kriteria eksklusi pada penelitian ini adalah pasien fraktur elbow yang disertai dengan penyakit lain, loss follow up, meninggal dunia, atau tidak mematuhi aturan pengobatan. Pemilihan sampel pada penelitian ini menggunakan teknik total sampling seluruh pasien yang memenuhi kriteria inklusi dan eksklusi akan langsung menjadi sampel dalam penelitian. Penelitian ini menggunakan bantuan perangkat lunak SPSS versi 20.0, data kemudian dilakukan analisis secara deskriptif berdasarkan karakteristik dari pasien fraktur berdasarkan jenis klemain, lokasi fraktur, dan mekanisme cidera fraktur.

\section{HASIL}

Sampel yang diperoleh merupakan pasien yang datang berobat ke RSUP Sanglah Denpasar dengan keluhan nyeri pada siku, keterbatasan ruang geraksendi (ROM), atau tampak deformitas pada siku dan di diagnosis sebagai fraktur elbow selama kurun waktu tanggal 1 Januari 2012 - 31 Desember 2013 yang telah masuk dalam kriteria yang telah ditetapkan. Sampel yang didapat sebesar 15 sampel. Laki-laki cenderung lebih banyak untuk mengalami fraktur elbow dibandingkan dengan perempuan yaitu dengan proporsi $73 \%$, berdasarkan penyebab fraktur keseluruhan sampel disebabkan oleh jatuh saat beraktifitas, berdasarkan jenis fraktur lebih banyak subjek yang mengalami fraktur suprakondiler humerus dibandingkan dengan fraktur olecranon yaitu dengan proporsi 93\% (Tabel 1).

\section{PEMBAHASAN}

Pada penelitian ini, didapatkan jumlah penderita fraktur elbow pada anak-anak di RSUP Sanglah pada tahun 2012-2013 yang berjenis kelamin laki-laki adalah lebih banyak yakni sebanyak 11 orang (73\%) dan perempuan sebanyak 4 orang (27\%). Hal yang berbeda disampaikan oleh Houshian dkk. (2001)

\section{Tabel 1 Karakteristik pasien fraktur elbow di RSUP Sanglah periode 2012-2013}

\begin{tabular}{lcc}
\hline Karakteristik & Frekuensi & Presentase \\
\hline Jenis kelamin & & \\
$\quad$ Laki-laki & 11 & $73 \%$ \\
Perempuan & 4 & $27 \%$ \\
Penyebab fraktur & & \\
$\quad$ Jatuh saat beraktifitas & 15 & $100 \%$ \\
$\quad$ Kecelakaan lalu lintas & 0 & $0 \%$ \\
Jenis fraktur & & \\
Suprakondiler humerus & 14 & $93 \%$ \\
Olecranon & 1 & $7 \%$ \\
Jumlah & 15 & $100 \%$ \\
\hline
\end{tabular}


dalam jurnalnya yang berjudul The Epidemiology of Elbow Fracture in Children, dimana angka kejadian fraktur elbow pada kelompok usia anak-anak ditemukan lebih banyak pada perempuan yakni sebanyak 191 orang (54\%) sedangkan pada lakilaki 164 (46\%) orang. ${ }^{3}$ Sedangkan berdasarkan faktor risiko yang menyebabkan terjadinya fraktur elbow pada kelompok usia anak-anak pada tahun 2012-2013 semuanya disebabkan akibat jatuh saat beraktifitas yakni sebanyak 15 orang (100\%). Berdasarkan penelitian yang dilakukan oleh Parent dkk. (2008), fraktur pada anak lebih sering terjadi dikarenakan sistem muskuloskeletal yang belum matang, hal ini disebabkan pada anak lebih rentan terhadap robekan pada permukaan sendi, lempeng epifiseal, insersia pofiseal dari satuan otot tendon yang besar. ${ }^{1}$ Hampir dari kebanyakan kasus fraktur pada anak-anak terjadi pada elbow dikarenakan pada usia 5-10 tahun anak-anak tersebut sedang dalam proses pematangan tulang dan pada usia tersebu tanak-anak rentan mengalami fraktur akibat dari aktifitas fisik yang dilakukan oleh anakanak seperti bermain dengan teman sebayanya atau sedang berolahraga sehingga menyebabkan jatuh.

Jika dilihat dari jenis frakturnya, pada penelitian ini ditemukan jenis fraktur suprakondiler humerus adalah yang terbanyak yakni 14 orang (93\%) sedangkan jenis fraktur lainnya seperti fraktur olecranon sebanyak 1 orang (7\%). Dalam survey fraktur pada anak-anak tahun 1950-1979 risiko fraktur supracondylar humerus ditemukan dua kali lipat lebih berisiko dibandingkan fraktur skeletal lainnya. ${ }^{4}$ Daerah suprakondiler humeri merupakan daerah yang relative lemah pada ekstremitas atas. Di daerah ini terdapat titik lemah, dimana tulang humerus menjadi pipih disebabkan adanya fossa olecranon di bagian posterior dan fossa coronoid di bagian anterior. Maka mudah dimengerti daerah ini merupakan titik lemah bila ada trauma di daerah siku. $^{5}$

\section{SIMPULAN}

Prevalensi fraktur elbow pada anak-anak di RSUP Sanglah Denpasar pada tahun 2012-2013 sebanyak 15 kasus, seluruhnya disebabkan karena terjatuh saat beraktifitas. Jenis fraktur elbow yang ditemukan pada anak-anak terbanyak adalah fraktur suprakondiler humerus yakni 14 kasus.

\section{DAFTAR PUSTAKA}

1. Parent S, Wedemeyer M, Mahar AT, Anderson M, Faro F, Steinman S, et al. Displaced olecranon fractures in children: a biomechanical analysis of fixation methods. J Pediatr Orthop. 2008;28(2):147-151.

2. Bashyal RK, Chu JY, Schoenecker PL, Dobbs MB, Luhmann SJ, Gordon JE. Complications after pinning of supracondylar distal humerus fractures. J Pediatr Orthop. 2009;29(7):704-708.

3. Houshian S, Mehdi B, Larsen S. The epidemiology of elbow fracture in children analysis of 355 fractures, with special reference to supracondylar humerus fracture. Jpurnal of Orthopaedic Science. 2001;6(4):312-315.

4. Landin LA. Fracture patterns in children. Analysis of 8.682 fractures with special reference to incidence, etiology and secular changes in a Swedish urban population 1950-1979. Acta Orthop Scand Suppl. 1983;202:1-10.

5. Lee SS, Mahar AT, Miesen D, Newton PO. Displaced pediatric supracondylar humerus fractures: biomechanical analysis of percutaneous pinning techniques. J Pediatr Orthop. 2002;22(4):440-443.

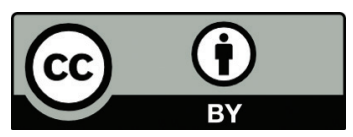

This work is licensed under a Creative Commons Attribution 